\title{
Editorial: Political Marketing: Voters, Political Parties, Candidates and Elections
}

\section{Dr. Peter Reeves}

\section{Salford Business School, University of Salford, UK}

This special edition complements and extends research in political marketing by examining its theory and practice with particular emphasis to the United Kingdom and the United States. From the submitted papers we can see how increasingly: (i) aspects of consumer behaviour theory is being applied to political marketing; (ii) political parties are implementing some of the strategies, tactics and practices of political marketing, and: (iii) elements of political marketing has potential to operate during election campaigns.

The publication of papers from the UK and US is illuminating as it can be argued that both democracies are at a crossroads and have the potential to influence geopolitics more widely. In the UK there is a referendum in 2016 which will decide whether the UK wishes to remain or leave the European Union. In early 2017 in the US, there will be a new President in the White House, which inevitably affects both US domestic and international affairs. At the time of writing, the outcome of these two events is too close to call, but 2016/7 are likely to be landmark years for international politics based on events in both the US and UK.

Although the impact of political events in the US and UK may have significant effects on international politics, the two political systems have contrasting political marketing and campaigning landscapes (e.g. Baines, Scheucher and Plasser, 2001). For example in the US political campaign consultancy is much more developed than in the UK. Moreover the amount of resourcing to fund political campaigns in the US is substantially greater than in the UK. The UK has strict rules regarding funding of political campaigns. Moreover the execution of political campaigns is more restricted in the UK, for example there is very limited opportunity in the UK (other than party election broadcasts) to run political advertisements on television, whereas in the US political advertising is common place. However there are some similarities between the US and the UK. First political marketing and campaigning operates between parties and politicians in a critical and politically confrontational environment. Second both countries have a long tradition of independent and critical free press and media which continuously attempts to challenge and hold to account politicians and political parties. Third, in the academic arena both countries have a strong tradition of university academics analysing political campaigns in order to build, extend and test theories to better understand political campaigns and voter behaviour.

\section{$\underline{\text { The Papers }}$}

Rick Ridder and Michael Dabbs are experienced US based political consultants who have kindly contributed a commentary to this special edition. They draw upon Lodish and Mela (2007) to argue that political candidate brands need to be built over the long term to be successful. They support their arguments by drawing from a range of US Presidential candidate hopefuls taking part in the 2016 US primaries. In particular they offer comment on the long term brand building activities of Donald Trump and Hillary Clinton. 
Natalie Wood and Feng Shen examine the impact of facial similarity between a political candidate and celebrity endorsers. Their findings suggest that where a political candidate is unfamiliar that the political candidate will be evaluated more positively where a celebrity endorser has a higher degree of facial similarity with the political candidate, than would be the case where a celebrity endorser has lower levels of facial similarity with the political candidate. They furthermore find when using Duncan's (2005) personal political salience (PPS) construct that voters with lower PPS tend to have a more positively pronounced influence in their evaluation of an unfamiliar political candidate when that political candidate and celebrity have facial similarity, than voters with higher PPS.

Neil Bendle and Matthew Thomson examine using an analytical modelling and experimental methodology the impact of indirect prejudice when voters consider other voters' preferences during a primary election. They conceptualise indirect prejudice as where a voter themselves may not be prejudiced but they judge other members of the electorate to be prejudiced. As a result of this perceived prejudice on the part of other voters in primary elections, an indirectly prejudiced voter may vote strategically because of their perceptions of other prejudiced voters. However this strategic voting creates a 'moral dilemma', according to the authors, who fear that voters may over-predict the prejudice of other voters.

Mona Moufahim, Michael Parsons and Patricia Rees employ discourse analysis (e.g. Benoit, 2007; Wodak and Meyer, 2015) to analyse UK political party leaders speeches with respect to immigration policy in the UK. They analyse speeches with immigration content made in 2013/14 by Nigel Farage (United Kingdom Independence Party), Ed Milliband (Labour Party), David Cameron (Conservative Party), and Nick Clegg (Liberal Democrat Party).

Brendan Richardson adopts a critical interpretation of the political marketing area, and argues that the election of Jeremy Corbyn as Leader of the Labour Party in Britain may present opportunities, if managed correctly, to redress voter disengagement. He suggest through the prism of consumer culture literature that the election of Corbyn may lead to the development of a brand community (Muniz and O'Guinn, 2001) based on the bottom up form of politics Corbyn has espoused. Hence he argues there may be potential for social reaggregation among consumer citizens

Nadia Kaneva and Austin Klemmer introduce the concept of what they term 'brandidates' as exemplars of branded political candidates. They assert using examples from the US and UK that brandidates have an enriched ability to speak to consumers in their own terms via well researched and delivered messages that are entertaining and interactive. Brandidates they argue create brand narratives based on their personal stories that 'humanize', 'personalize', 'authenticate' and 'idealize' political leaders. Thus the brandidate acts a form of 'emotional labour' for voters.

\section{$\underline{\text { A Vote of Thanks }}$}

This special edition would not have been possible without the authors who have worked extremely hard in producing the high quality papers which form this collection. Collectively they have responded very well throughout to peer review and editorial review processes, 
submitting their work to tight schedules inevitable with a special issue of a journal. I would also like to thank reviewers who have given their valuable time to this project. I was able to establish an international review panel who are experts in the specific areas underpinning the published papers. In 2015, Emeritus Professor Stan Paliwoda first approached me to ask if I would undertake the Guest Editorship of this Special Edition. As this is the first time I had edited a Journal I was at first a little unsure, but he encouraged me and offered me words of advice when I required it. I am glad that I did take up the offer of editing this special edition, as it has enabled me to see how much effort and dedication is required by Journal Editors. This will help me in my own publishing activity moving forward. I would also like to publically express my thanks to the editorial administrative assistance provided by the Fiona Lees and Anne Foy at Westburn Publishers.

I am confident that what this special edition does it to put forward a thought provoking and leading collection of articles in aspects of political marketing. The methods used in some of the papers are innovative and also offer advances in the field of political marketing. It is also good to see new voices emerging in the field of political marketing. I am of the view that political marketing is an important research area which needs to be published in mainstream marketing journals, as further understanding decisions processes of voters is most vital for societies.

\section{Biography}

Dr. Peter Reeves is Lecturer at Salford Business School. He was educated at the University of Birmingham where he earned a Bachelor of Commerce Honours Degree, an MSc in Economic Development Research and Policy and a Doctorate in Commerce. He has held the Joseph Chamberlain Scholarship. His main research interests include political marketing and brand marketing. He has published in the European Journal of Marketing, Journal of Brand Management, Journal of Non-profit and Public Sector Marketing, and has contributed to papers in leading international conferences such as the World Marketing Congress, European Marketing Academy Conference etc. Dr. Reeves serves on the Editorial (Advisory) Board of the Journal of Marketing Management. He is Fellow Member of the Academy of Marketing Science, Member of the Academy of Marketing and Fellow of the Higher Education Academy.

\section{$\underline{\text { Address for Correspondence }}$}

Dr. Peter Reeves, Salford Business School, University of Salford, Salford, Greater Manchester, UK. Tel No: +44(0)161 295 5720. Email: P.Reeves@ salford.ac.uk

\section{$\underline{\text { References }}$}

Baines, P.R., Scheucher, C. \& Plasser, F. (2001). The "Americanisation" myth in European political markets - A focus on the United Kingdom. European Journal of Marketing, 35(9/10), 1099-1117. http://dx.doi.org/10.1108/eum0000000005961

Benoit, W.L. (2007). Communication in political campaigns. New York: Peter Lang. 
Duncan, L.E. (2005). Personal Political Salience as a Self-Schema: Consequences for Political Information Processing. Political Psychology, 26(6), 965-976.

http://dx.doi.org/10.1111/j.1467-9221.2005.00453.x.

Lodish, L.M. and C. F. Mela (2007). If brands are built over years, why are they managed over quarters?, Harvard Business Review, 85 (7-8), 104-112.

Muniz, A.M. \& O'Guinn, T.C (2001). Brand Community. Journal of Consumer Research, 27(4), 412-432. http://dx.doi.org/10.1086/319618.

Wodak, R., \& Meyer, M. (Eds.). (2015). Methods of critical discourse studies, $3^{\text {rd }}$ Edition, London: Sage. 